\title{
Redefining the Role of the Human Resource Professional (HRP) in the Nigerian Public Service for Enhanced Performance
}

\author{
Benjamin J. Inyang ${ }^{1} \&$ Juliana B. Akaegbu ${ }^{1}$ \\ ${ }^{1}$ Department of Business Management, University of Calabar, Calabar, Nigeria \\ Correspondence: Benjamin J. Inyang, Ph.D., Department of Business Management, University of Calabar, Calabar, \\ Nigeria. Tel: 234-80-3377-3403. E-mail: benji1955.unical@yahoo.co.uk
}

Received: December 31, 2013

Accepted: January 12, 2014

Online Published: January 16, 2014

doi:10.5430/ijba.v5n1p90

URL: http://dx.doi.org/10.5430/ijba.v5n1p90

\begin{abstract}
The Nigerian public service is a product of British colonial administration, and it has since after independence in 1960, metamorphosed to a huge and complex system for harnessing the country's resources to facilitate economic growth. The public service has over the years undergone several reforms to make it more effective and efficient in service delivery. These reforms have not significantly improved the service offerings of the public service, due to its politicization, lack of neutrality and poor human resource management practices, where non-professionals without requisite skills and knowledge were made to handle the HR function.

This paper seeks to explore the gamut of human resource management practices that must be entrenched in and to reposition the public service for higher performance. It further identifies the role or responsibility and bench-skills and knowledge of the HR professional that will enhance optimum service delivery in the sector. The paper adopts the methodology of documentary analysis of current relevant literature. The issue of failed public enterprises and poor performance of the Nigerian public sector is of serious concern to both the people and government and has therefore attracted a plethora of public commentary.

The paper finds that the reforms of the public service were often structural in nature and paid little attention to the people-factor and people-management issues. HR professionals were not engaged to handle people as strategic resources, rather personnel administrators who lack professional expertise and competence were appointed to provide transactional and administrative support in the public service. This does not enhance strategic goal attainment and the competitive position of the public enterprises. The paper recommends a shift in paradigm and the engagement of HR professionals who have the expertise to design and implement human resources management strategies that can drive service delivery and enhance effectiveness and efficiency. The HR professional facilitates the development of high performing and competent workforce.
\end{abstract}

Keywords: public service, human resource professional, human resource management, public service reform, Nigeria

\section{Introduction}

The public service of any nation is an institution of governance and administration established essentially to deliver public good to the people in the most efficient and effective manner. The Nigerian public service is a product of colonialism, established as an instrument for expediently implementing the administrative structure and activities of the British colonialist from the late $19^{\text {th }}$ century. It has since after independence in 1960, metamorphosed to a huge and complex system for harnessing the country's resources to facilitate economic development (Inyang, 2008). Its roles, among others, is "to carryout the burden of planning and dealing with the problems of growth and development in order to transform our natural resources into goods and services that would meet the rising expectations that come with political independence" (Mamser, 1992:298). The public service is therefore an influential public institution, which is "an instrument of public service delivery and development" (Kauzya, 2001:3).

With its huge size comes the array of problems affecting efficiency and effectiveness in the system. Several reforms have been carried out since after independence aimed at improving public service delivery. These reforms have not significantly improved the service offerings of the public service, due to its politicisation, lack of neutrality and poor human resources management practices, where non-professionals and without requisite skills and knowledge were made to handle the human resource function. 
The series of reforms carried out over the years tended to be structural in nature and paid little attention to the people-factor and people-management issues. HR professionals were not engaged to handle people as strategic resources, rather personnel administrators who lack professional expertise and competence were appointed to provide transactional and administrative support in the public service. This does not enhance strategic goal attainment and the competitive position of the public enterprises and the public service in general.

This paper seeks to explore the gamut of human resource management practices that must be entrenched in and to reposition the public service for higher performance, drive economic growth and become competitive on the same pedestal with the private sector. The paper further identifies the role or responsibility and bench skills, competencies and knowledge of the HR professional that will enhance optimum service delivery in the sector.

The paper is divided into seven sections. The introductory section is followed by the literature review which briefly explores the Nigerian public service reforms and the concept of human resource management. Section three states that research methodology. Section four presents a discussion of the role of the HRP in the public service and this is followed by recommendations and the limitation of research and the direction for further research. The final section presents the conclusion.

\section{Literature Review}

\subsection{The Nigerian Public Service and Its Reforms}

The terms civil service and public service are often used interchangeably although there are subtle differences between them. Civil service usually means the functionaries of states appointed to government jobs, through non-elective process. It refers to all employees of government (federal, state or local governments) ministries and departments that are charged with the responsibilities of implementing policies and making input into policy formulation. The civil service as an institution of governance has the responsibility to design, formulate and implement public policy as well as discharge government functions and development programmes in an effective and efficient way.

The public service is broader and more inclusive than civil service, and it refers to government parastatals, which are the operational arms of government ministries, departments and agencies (MDAs). The paper adopts the nomenclature of public service which is inclusive of civil service and encompasses the Armed Forces, the Judiciary, the Police, government institutions, parastatals, government-owned companies and statutory agencies. The public service is therefore the entire government's conglomerate which is directly responsible for managing government businesses and investments, including the provision of security, infrastructures and governance for the people at the grass root. In other words, the public service is a huge complex system or bureaucracy to facilitate economic development and providing services to its citizens either directly or by financing private provision of the services. It is the custodian of rules and regulations and the engine of development.

The public service in Nigeria as an institution of governance is a three tier structure made up of:

i. Federal-level: The major and central public bureaucracy and instrument which government uses to regulate and manage all aspects and areas of the society. Government allocation of resources passes through this huge bureaucracy, which drives national development.

ii. State-level: The public service at this level is limited in scope and enjoys a measure of autonomy. It drives development nearer home to the people.

iii. Local-level: Officials employed in the local government are also civil servants. This level derives grassroots development providing social infrastructures like road, pipe-borne water, rural health care centres, etc for the people.

The focus of our discussion here is the federal level public service which is the major and central public bureaucracy and institution which impacts on all levels of governance and is the centre of successive public sector reforms in Nigeria. The Nigerian public service is designed to create public values in the following areas: economic development, sustains political and social cohesion, provides the legal and administrative environment for private business, effective and efficient fiscal management, affects production decision and cost through regulatory controls and drives government allocation of resources for the different areas of the society, directly or indirectly.

These public values have not been satisfactorily achieved over the years as the public service experienced serious managerial problems affecting efficiency and effectiveness. There is a general opinion that most of the public enterprises in Nigeria have failed to deliver on the purposes for which they were established. Management ineffectiveness and inefficiency have been advanced by practitioners and researchers of public enterprises as the bane of the Nigeria public sector (Tokunboh, 1990). Agagu (2008:243) asserts that: 
"The public service which was seen as the custodian of rules and regulations and the engine of the development had lost its prestige and confidence. The aftermath of this is the invention of series of reforms which, have led to privatization, downsizing and right-sizing of the public service and even minimizing the role of the public sector in the national life".

The public service was considered a more efficient and functional institution and the pride of the nation in the years immediately after independence. The Nigerian delegation's report in African Training and Research Centre in Administration for Development (ATRCAD), Morocco (2000: 2) states that the government as at May 1999 "inherited a civil service which was a mere shadow of an effective and result-oriented, politically neutral, loyal, professional and customer-friendly civil service that had existed before the advent of the military intervention in politics". The different reforms introduced during the long period of military regimes in the country (1966-1979) and (1984-1999) resulted in the politicisation of the system which quickly lost its neutrality, and began to experience system decline in efficiency and effectiveness. Interestingly, however, this trend has not abated even with the further reforms initiated under democratic governance or dispensation from 1999 to date.

Public service reform refers to the deliberate changes in the structure, organisation and processes of the civil service and public sector organizations in other to make them more effective and efficient in service delivery. Public service reforms are often initiated to enable the system achieve developmental goals and targets, enhance service delivery and to create values for the citizenry.

The table below shows the series of post-independence public services reforms carried by the government. The table identifies the main objective or focus of each reform. The common rationale of the different reforms is usually to enhance system efficiency and effectiveness, creation of values and quality service delivery, national development, and to ensure corruption free public service.

Table 1. Post-independence Public Service Reforms (PSR) in Nigeria

\begin{tabular}{|c|c|c|c|}
\hline $\mathbf{S} / \mathbf{N}$ & $\begin{array}{l}\text { Designation of Reform } \\
\text { Commission/Panel }\end{array}$ & $\begin{array}{l}\text { Year of } \\
\text { reform }\end{array}$ & Main Objective/Focus of PSR \\
\hline 1. & Morgan Commission & 1963 & $\begin{array}{l}\text { Reviewed salaries and wages in public service. } \\
\text { Minimum wage introduced }\end{array}$ \\
\hline 2. & Eldwood Commission & 1966 & $\begin{array}{l}\text { Determined appropriate or equitable grading system } \\
\text { in the public service }\end{array}$ \\
\hline 3. & Adebo Commission & 1971 & $\begin{array}{l}\text { Reviewed the existing salaries and wages in the public } \\
\text { service and parastatals; restructured the entire civil } \\
\text { service }\end{array}$ \\
\hline 4. & Udoji Commission & 1974 & $\begin{array}{l}\text { Undertook a compressive reform of the civil service } \\
\text { in terms of organisation, structure and management }\end{array}$ \\
\hline 5. & Dotun Phillips Commission & 1985 & $\begin{array}{l}\text { Reviewed the structure, composition and methods of } \\
\text { operations of the public service. }\end{array}$ \\
\hline 6. & $\begin{array}{l}\text { Civil Service Reforms } \\
\text { Decree No } 43 \text { of } 1988\end{array}$ & 1988 & $\begin{array}{l}\text { Restructured and politicised the upper echelons of the } \\
\text { civil service and political appointees introduced as } \\
\text { accounting officers }\end{array}$ \\
\hline 7. & Ayida Review Panel & 1994 & $\begin{array}{l}\text { Reviewed and reversed the } 1988 \text { reforms, } \\
\text { re-introduced careerism and restored permanent } \\
\text { secretary cadre. Introduced structural changes. }\end{array}$ \\
\hline 8. & $\begin{array}{l}\text { Civil Service Reforms Under President } \\
\text { Olusegun Obasanjo }\end{array}$ & $1997-2007$ & $\begin{array}{l}\text { Introduced SERVICOM-(Service compact with } \\
\text { Nigerians) - a service delivery watchdog to restore } \\
\text { efficiency in government. The major thrusts of reform } \\
\text { were pension reform, monetisation policy, } \\
\text { re-organisation of MDAs, payroll reform and review } \\
\text { and update of public service rules and financial } \\
\text { regulations. }\end{array}$ \\
\hline 9. & Steven Oransanya Daniel & $2010-2013$ & $\begin{array}{l}\text { Reviewed organisational structure of the entire public } \\
\text { service with focus on rationalisation of departments } \\
\text { and ministries (Government is yet to issue a white } \\
\text { paper on the recommendations of the report of the } \\
\text { panel as at the time of writing this paper). }\end{array}$ \\
\hline
\end{tabular}

Source: Authors' Research 
The general verdict by scholars and commentators is that the plethora of reforms by successive governments has not improved the Nigerian public service. The reforms have not been able to impact on service delivery or enhance greater efficiency and effectiveness of the system or make the sector competitive. Ikeji (2013) notes that the different reforms undertaken in the face of poor public service delivery in Nigeria, had varying outcomes, and these have not added any significant improvement or value in system. The failure of the public service, to achieve its desired outcomes has been attributed to several factors by scholars: management ineffectiveness and inefficiency(Tokunboh, 1990), institutional defects and human frailty (Mamser, 1992), faulty diagnosis and prognosis arising from human resources problem and management issues of leadership (Olowu, 1999), poor recruitment policies (Briggs, 2007), lack of human resource capacity building (Inyang, 2008), workforce inefficiency and wastefulness (Adamade, 2008), lack of political will (El-Rufai, 2011), administrative attitude and behaviour (Eme \& Ugwu, 2011), political patronage, cultural, structural and institutional defects (Anazodo, Okoye \& Chukwuemeka, 2012), politicisation and quota system of recruitment (Nwanolue \& Iwuoha 2012), and lack of democratic practices in the management of public institutions (Bayo, 2012). The former President of Nigeria, Olusegun Obasanjo (2003) observes that:

"Nigerians have too long been feeling short-changed by the quality of public service. Our public offices have too long been showcases for combined evils of inefficiency and corruption, whilst being impediments for effective implementation of government policies. Nigerians deserve better. And will ensure they get what is better".

In its editorial comments, the Guardian (2013:2) notes that: "All these efforts have either not been well implemented or have since gone into limbo. The result is a civil service that gives little service to Nigeria and does little good to its own image".

The various attempts to reform a non-performing public sector are easily concerned with introducing structural changes which hardly impact on service delivery since the people elements are not given due consideration. The government needs to take a critical look at the capabilities of their human resources in order to tap their full potentials for enhanced performance in the public service. The government needs to engage the services of the HR professionals who would help to shape and develop new directional focus in line with the new management approach to drive greater efficiency and effectiveness in the human resource management practices and enhance public sector performance.

The government must embrace the modernizing imperatives of the global public service by re-inventing the Nigerian public service, driven by the New Public Management revolution. The application of the new management techniques and skills in the running of a bureaucracy must be in consonance with globalization and information technology to enhance cost effective service delivery. This new public sector revolution is characterized by a paradigm shift from the traditional administrative framework to a management approach that requires managers to manage within an enterprise culture guided by the constraining values of economy-effectiveness-efficiency. Olaopa (2011) sees managing in the public service as involving the generic management principles of getting things done as quickly, cheaply and effectively through efficient human resources. This emphasises the core values of people, integrity and excellence in the public service.

The continual engagement of non-professionals in the public service to perform the strategic HR function has not added any significant value to the system in terms of efficiency and effectiveness. The Chartered Institute of Personnel Management of Nigeria (CIPM), the foremost human resource management institute, had at different fora expressed concerns about the increasing rate of quackery in human resource management practice in the Nigerian public service (Popoola, 2010). The situation where non-professionals with no requisite people-management knowledge, training and skills head the public sector organizations and agencies encourages lack of professionalism, and results to poor performance and low quality service offerings in the public sector.

\subsection{Human Resource Management (HRM) and Its Value}

The problem of the Nigerian public service can simply be reduced to the problem of the human factor - how it is acquired, managed, developed and maintained in the service. The human resources are the people that constitute the workforce in the public service. It is, in fact, the essential element and the building block that gives life and energy to the public service, converting other resources into products use for the benefits of the system (Inyang, 2001).

Human resource management is defined as the "formal system for the management of people within the organization" (Bateman and Zeithaml, 1993:346). HRM is essentially concerned with all activities that contribute to successfully attracting, developing, and motivating and maintains a high-performing workforce and that result in organizational success (Inyang, 2011). The proper management of people as organizational assets and the adoption of appropriate 
human resources policies, practices and strategies enhance organization's performance and competitiveness. A robust HRM policy is required "to ensure that the service is run by people whose training, experience, motivation and mental state of mind are positively aligned to the needs and aspirations of the government and the people they serve (ATRCAD, 2000:3).

In this age of globalization and competition no one would doubt the prime position of the human resource in the wealth creation process of an enterprise or a public service. Ndiokho (1998:6) captures this point when he states that "it stands to reason, that any enterprise or country which is unable to develop the skills and knowledge of its human resource, and utilize such skills effectively and efficiently in corporate as well as national development, cannot grow". Adegoroye (2005: 1) adds that "The public service reflects the state of the nation and no nation has been able to advance beyond its public service". Balogun (2003:4) notes that the "development of any nation depends to a very large extent on the calibre, organization and motivation of its human resources". People are, in fact, the critical factor in achieving enterprise success. To achieve continuous improvement will require the organization or enterprise, thinking out of the box, acting, developing its human resources, creating supportive relationships, strategies and structures and accommodating new technology in the work process. All of these are people- driven activities which the practitioners of human resource management must contend with for their organisation to be strategically positioned to achieve the corporate objectives.

The people-factors must be given serious attention in the public sector, like is the case in the private sector, which has abiding faith in its human resources, plan adequately for employees to unleash their creative potentials for the dual benefits of the organization and themselves. (Korodo, 2000:2) notes that:

"The private sector organisations are turning round to give more attention and focus on people and people issues and the public sector cannot be totally insensitive to the development. Employees remain the soul of and personality of organisation which otherwise is inanimate and can only come alive with people factor as it determines the true competitive position of the organisation".

The nexus between the HR function and the public service is obvious. It is the strategic resource that the public sector needs for success and survival in an increasingly complex and turbulent business environment. Our world of today is one where quality, efficiency and competitiveness count most. The public service must show avid commitment for HR capacity building to avoid human obsolescence, which is deterioration in the skills, knowledge and performance of an employee due especially to lack of effective training and development programmes. HR capacity building will help the public service by adding value to its key resources, that is, the employees by bringing to the fore, their creative potentials.

Onah (2012) acknowledges the unfortunate situation where less than satisfactory attention is given to issues of human resource management in the public sector organizations in Nigeria. This poor management of the HR function has resulted in the progressive decay of public enterprises with concomitant poor service delivery.

\section{Methodology of Study}

The paper adopts the methodology of documentary analysis of current literature which enhances critical and contextual analysis of issues. The issue of failed public enterprises and poor performance of the Nigerian public sector is of serious concern to both the people and government and has therefore attracted a plethora of public commentary.

\section{Human Resource Professional in Public Service}

The problem of the Nigeria public sector is reducible to the central problem of poor management of the human resource and the function. Inyang (2011:142) considers the human resources as "not only the knowledge, skills and abilities of organisational members under direct employment relationship but also the behaviours they exhibit". As a strategic resource, the HR function focuses on building the human capital that drives organizational operations and activities. Armstrong (2005) identifies two key roles of HR function to include:

i) Ensuring that management deals effectively with everything concerning the employment and development of people, as well as employment relationships between management and the workforce.

ii) Creating a conducive environment that enables people to make the best use of their capacities and to realize their potential to the benefit of both the organization and themselves.

The public service needs an HR professional who is now considered a strategic business partner and whose responsibility transcends the traditional, transactional and administrative roles of the HR function of the past. The HR professional is considered as a certified expert who possesses the theoretical knowledge, skills and practical 
experience in the management of human resources in the organization. The paradigm shift from the practice of personnel administration which is generalized in the public service to professional HRM where the HR professional as specialist can design and implement new strategic plans focused on achieving business objectives optimally is a desideratum. With a shift in responsibility, the HR professional now demands a seat at the boardroom to be able to contribute significantly to decisions about strategic people-issues and as well as drive the implementation process. The HR function has become more strategic, proactive, commercial and professional. This paradigm shift, according to Wiafe-Asinor (2013:42), has meant that "HR's agenda has expanded to include all aspects of people processes which can deliver organizational effectiveness such as: the right people, the right culture, the right leadership, the right organization design, the right change management and the right people process".

The HR professional in his leadership position of people manager, must be creative to facilitate the effective management of the employees to enable the HR function add value to the public service. The focus should be on both the individual employee as he does his assigned task and seeing that his task actually contributes significantly to the goal of the public service and not otherwise.

The HR professional needs continuous training and retraining to be able to manage people effectively. Onah (2003) notes that the management of human resources is poorly undertaken and this affects the implementation of public sector projects. Training and retraining of the HR professionals is to enable them adapt to the changes and challenges in the global business environment and drive efficient public service operations

The HR professional, as a strategic business partner, can deliver value in the organization in four ways according to Ulrich (1997):

i) HR should become a strategic partner with senior and line managers in executing business strategy and helping to improve planning from the boardroom to the market place.

ii) HR should become an administrative expert in the way work is organised and executed and to deliver administrative efficiency to ensure cost reduction and quality products and services.

iii) HR should become a champion for employees, by representing their interest to senior management, and working to increase employees' contribution, that is, their commitment to the organisation and their ability to deliver results.

iv) HR should become a change agent, by shaping process and culture that together improve an organisation's capacity for a change.

The public service must re-invent or re-engineer its human resource management practices and policies and professionalise the system by engaging the HR professionals in the effective management of the human assets, and in a business-like manner, to remain competitive and deliver value to the citizens. The African Charter for Public Service, Windhoek (2001:8-9), Article 21 states clearly that:

"Professionalism resides in how skillfully and how well a public service employee performs his/her functions and duties. Professionalism manifest itself in the public service employee's behaviour at work and in his/her constant effort to improve, reinforce and update his/her knowledge, refine the skills that are necessary for carrying out his/her tasks and enhancing his/her output and productivity"

HR strategy must be incorporated in public service reform process to enhance the sector's capacity to deliver valued service. Merits as the first criterion of recruitment policy (and not the quota system) must be mainstreamed into the public service to enhance the re-invention of the sector. The use of objective criteria for recruitment into the public service will enhance the system's efficiency and effectiveness as well as equity and transparency. This should be followed by improving the reward system to attract competent applicants and also reduce labour turnover in the service.

For the HR professional to function effectively as a strategic business partner in the public service he needs the following critical skills:

i) Leadership skills: having the ability to create a vision and strategy and to ensure the alignment of the public civil organistion with the strategy and being able to manage and motivate the employees as a team.

ii) Business skills: needs private sector orientation of understanding the dynamics of business. He must possess the financial acumen and to understand HR metrics to effectively communicate how HR strategies impact on the bottom line. He must have the business acumen and ability to translate business strategies into effective HR strategies. 
iii) Technology skills: ability to develop proficiency in broad HR applications and how they can be applied to deliver value in the public service.

iv) Global mindset: Since the public service is operating in a global environment the HR professional must develop a global mindset to understand the global marketplace and strive to put the public service on a competitive pedestal with the private sector

v) High knowledgeability: The HR professional needs to broaden his horizon, seek more knowledge and information to manage the human capital effectively. He needs to be multi-skilled, self-responsible, visionary and able to learn, to handle and to lead the public service organization to success

The acquisition of these skills or competencies will help the HR professional to provide maximum contributions to the leadership and bottom line in the public service. Burton (2003) identifies three major role challenges of HR professional in this regards as: Firstly, the need for HR managers to become more vocal and influential in the boardroom alongside the financial and marketing directors. Secondly, the need to have quantitative skills such as measurement of human work and the understanding of organizational structure and dynamics to provide effective service in organizations. Thirdly, HR professional needs to develop a new set of skills and competence around visioning, systems thinking and organizational development and change management. Anyim, Ikemefuna and Mbah (2011) advise the HR professionals to articulate their role in terms of creating value and measuring their effectiveness in terms of business competitiveness and success.

\section{Recommendations: Strategies to Improve the Public Service}

The strategies for improving the public service include:

1. Professionalizing the HR practices in government. This could be done by working together with the Chartered Institute of Personnel Management of Nigeria, the foremost professional body for human resource management, to provide the necessary expertise.

2. Enacting the New Public Management guided by the values of economy, effectiveness and efficiency and driven by effective and efficient human resources.

3. Changing work culture to restore accountability, public trust and enforce code of ethics and emphasise ethical leadership.

4. Making fundamental changes to the structure and processes of the public sector organizations to make them perform better. The public service should be ICT-driven.

5. Continuing investment in capacity building to update skills and knowledge of employees.

6. Restoring meritocracy rather than the principles of federal character, quota system and catchment areas - and emphasizing performance-orientation, adequate reward system and creating conducive work environment.

7. Competency profiling. This is a process or a method for identifying the specific skills, knowledge, abilities, attitudes and behaviour needed to perform a task, job or career. Accessing the competencies of individual employees against job requirements and providing a clear guideline to employees enhances job performance and ensures that business outcomes are achieved.

8. Olaopa (2013:34) emphasises the need to create:

"a new generation of public service managers committed to the agenda of installing a new productivity paradigm in the public service, through evolving a new career management system leading to the acquisition of officers with high competencies, capabilities and skills and a robust learning and development system for constant re-skilling and re-tooling"

\section{Limitation and Direction for Further Research}

The general knowledge from the literature is that HR practices impact on organizational performance. However, the obvious limitation of this study is that it did not empirically assess the role of HR professionals in the Nigerian public service which would have helped us to know the extent of its contribution.

The direction of further research should be to test how the performance of the HR functions by HR professionals can contribute to improving the offerings of the Nigerian public service. Further research should be undertaken to understand the expectations of the millennials (the Generation Y - younger generation employees) in the service, in other to know what could aid them contribute significantly to improve public service performance or delivery. The expectations of Generation Y workforce tend to vary and totally different from their older and senior colleagues. The 
study should incorporate the need for HR professionals to understand the workforce under the millennial age range, examine how it could be developed, maintained, and motivated to achieve the public service goals efficiently and effectively. It is important to assess this area because the quality of human resource impact on service delivery.

\section{Conclusion}

The public service is a product of British colonial administration, established essentially as an institution of governance. The Nigerian public service, over the years, has experienced many teething problems that have affected the effectiveness and efficiency of the system. This has led the initiation of several reforms by successive governments aimed at improving the public sector.

The failure to engage HR professionals has been the bane of the Nigerian public service. Therefore, it is imperative emphasizing the need for HR professionals to be well appreciated and engaged in the Nigerian public service in other to gain an outstanding competitive edge in service delivery, in line with her private sector counterpart.

\section{Acknowledgements}

This paper was presented at the International Trade \& Academic Research Conference (ITARC) co-hosted by the Academy of Business \& Retail Management (ABRM) \& Journal of Business \& Retail Management Research (JBRMR), held at Holiday Inn London Regent's Park, London, UK, $4^{\text {th }}-5^{\text {th }}$ November 2013. The authors are grateful to the two anonymous reviewers for their comments and the conference participants for their invaluable inputs.

\section{References}

Adamade, S. S. (2008). Public sector in Nigeria: Implications for labour leadership. Nigerian Journal of Labour Law and Industrial Relations, 2(4), 95-110.

Adegoroye, G. (2005). Mainstreaming ethics and professionalism in the public service: The Nigerian experience. A paper presented at the Conference on the African Charter and Related Reforms, Swakopmund, Namibia, 3-7 October, 2005.

African Training and Research Centre in Administration for Development (ATRCAD). (2000). Workshop on management of human resources in Africa: Challenges for the third millennium (achievements made by Nigeria), Tangier, Morocco, 23-27 October 2000. Retrieved from http://www.upan/.un.org/intrudoc/group/public/documents/cafrad/upan0098.pdf

Agagu, A. A. (2008). Re-inventing the Nigerian public service in an era of reforms. Pakistan Journal of Social Science, 5(3), 244-252.

Anazodo, R. O., Okoye, J. C., F. \& Chukwuemeka, E. E. O. (2012). Civil service reforms in Nigeria: The journey so far in service delivery. American Journal of Social and Management Sciences, 3(1), 17-29. http://dx.doi.org/10.5251/ajsms.2012.3.1.17.29

Anyim, F. C., Ikemefuna, C. D., \& Mbah, S. E. (2011). Human resource management challenges in Nigeria under a globalized economy. International Journal of Economics and Management Science, 1(4), 1-11.

Armstrong, M. (2005). A handbook of human resource management practice $\left(9^{\text {th }}\right.$ ed.). London: Kogan Page.

Balogun, M. J. (2003). Nigeria's public service reform process: Human resources issues. Retrieved from http://www.unpanl.un.org/intro/groups/public/documents/CAFRAD/UNPAN011072.pdf

Bateman, T. S., \& Zeithaml, C. P. (1993). Management: Function and strategy ( $2^{\text {nd }}$ ed.). Burr Ridge, Illinois: Irwin.

Bayo, O. A. (2012). Federal civil service reform in Nigeria; The case of democratic centralism. Journal of Radix International Educational and Research Consortium, 1(10), 1-45.

Briggs, B. R. (2007). Problems of recruitment in civil service: Case of the Nigerian civil service. African Journal of Business Management, 1(6), 142-153.

Burton, L. (2003). The next big thing. People Dynamics, 21(2), 22-23.

El-Rufai, N. A. (2011). Reforming our dysfunctional public service. Retrieved from http://elombah.com/index.php/articles/nasir-el-rufai/8339-reforming-our-dysfunctionalpublic-service-nasir-el-ru fai-v15-8339

Eme, O. E., \& Ugwu, S. C. (2011). Developmental state bureaucracy in Nigeria. Restructuring for effectiveness (1999-2007). Arabian Journal of Business and Management Review, 1(4), 44-54. 
Guardian Editorial. (2013). Nigeria and its civil service. The Guardian Newspaper of Nigeria, $27^{\text {th }}$ August, 2013, pp. 1-2. Retrieved from http://www.ngrguardiannews.com/editorial/132079-nigeria-and-its-c...

Ikeji, C. C. (2013). Towards a better public service management in Nigeria: The 'target-setting' technique to the rescue. Public Policy and Administration Research, 3(6), 22-25.

Inyang, B. J. (2001). Harmonizing human resource management (HRM) practice in the public and private sector. Human Resources Management, 10(7), 8-14, 21.

Inyang, B. J. (2008). Human resource capacity building: An imperative for effective performance in the public service. MRL Journal, 2(Jan-March), 50-54.

Inyang, B. J. (2011). Creating value through people: Best human resource (HR) practices in Nigeria. International Business and Management, 2(1), 141-150.

Kauzya, J. (2011). A holistic model for managing ethnic diversity in the public service in Africa. Paper presented at United Nations Experts Group Meeting on Managing Diversity in the Civil Service. New York: United Nations Headquarters, pp. 1-11. Retrieved from www.UPAN.org.analytical-report.asp

Korode, S. F. (2000). People development: Key to improved organisational performance. A paper presented at the $3^{\text {rd }}$ Annual Eastern Zonal HR Practitioners Conference of the Chartered Institute of Personnel Management of Nigeria, held at Metropolitan Hotel, Calabar on $19^{\text {th }}-10^{\text {th }}$ March 2000, pp.1-10.

Mamser, Directorate for Social Mobilization. (1992). Social transformation for self-reliance: Proceedings of a National Conference. Ibadan: Foundation Publications.

Ndiokho, B. U. (1998). Beyond 2000: The human resource practitioners and national development. A paper presented CIPM week organized by the Rivers/Bayelsa State Branch of the Chartered Institute of Personnel Management of Nigeria held at the Hotel Presidential, Port Harcourt on $16^{\text {th }}$ July 1998, pp. 1-14.

Nwanolue, B. O. G., \& Iwuoha, V. C. (2012). The Nigerian civil service and promotion of sustainable human development: A critical analysis. Arabian Journal of Business and Management Review, 1(9), 12-21.

Obasanjo, O. (2003). On SERVICOM. Retrieved from http://www.servenigeria.com

Olaopa, T. (2011). Modernising the Nigerian public service and the challenges of complexity. Ibadan: Bookcraft.

Olaopa, T. (2013). Reforming the public service for excellence and ethical leadership. A paper presented at the $45^{\text {th }}$ Annual Conference of the Chartered Institute of Personnel Management of Nigeria held at the International Conference Centre, Abuja, 18-20 September 2013, pp. 1-46.

Olowu, B. (1999). Redesigning African civil service reforms. The Journal of Modern African Studies, 37(1), 1-24. http://dx.doi.org/10.1017/S0022278X99002943

Onah, F. O. (2003). Human resource management. Enugu: Fulladu Publishing Company.

Onah, F. O. (2012). Engaging the challenges of human resources management in public organizations in Nigeria. Being text of the $65^{\text {th }}$ Inaugural Lecture of University of Nigeria, Nsukka, Nigeria.

Popoola, A. (2010). CIPM rebrands, worries over quackery in public sector. The New Voice News. Retrieved from http://www.thenigerianvoice.com/nvnews/39797/1/cipm-rebrands-worries-over-quackery-in-public-sect.html

The African Charter for Public Service. (2001). Charter for the public service in Africa. Windhoek, Namibia, 5 February 2001. Retrieved from http://www.afrimap.org/english/images/treaty/AfricanPublicServiceCharter.pdf

Tokunboh, M. A. (1990). Public enterprise: The Nigerian experience. Lagos: Lantern Books.

Ulrich, D. (1997). Human resources champions: The next agenda for adding value and delivering results. Boston, Massachusetts: Harvard Business School Press.

Wiafre-Asinor, A. (2013). Organizational development for the leaders. A paper presented at the $45^{\text {th }}$ Annual Conference of the Chartered Institute of Personnel Management of Nigeria held at the International Conference Centre, Abuja, 18-20 September 2013, pp. 1-75. 